\title{
EFEKTIVITAS PEMBELAJARAN VEE DIAGRAM DALAM MEMINIMALISIR KESALAHAN PADA PERANCANGAN EKSPERIMEN
}

\author{
Handayani Handayani \\ Program Studi Pendidikan Biologi FKIP Universitas Kuningan \\ Jl. Cut Nyak Dien No. 36A, Kuningan, Jawa Barat, Indonesia 45513 \\ Email: handayani@uniku.ac.id
}

Doi: https://doi.org/10.31943/mangiferaeduv4i2.65

Received: 06 Desember 2019 Accepted: 27 Januari 2020 Published: 31 Januari 2020

Citasi: Handayani. 2020. Efektivitas Pembelajaran Vee Diagram Dalam Meminimalisir Kesalahan Pada Perancangan Eksperimen. Jurnal Mangifera Edu, 4(2), 94-106.

\begin{abstract}
Designing experiments is activity-based laboratory learning where laboratory activities lead to scientific ideas which emphasizes qualitative processes that aim to encourage conceptual changing toward the students. Experimental designs made by students are still found many mistakes. These in designing experiments could be minimized by applying vee diagrams. The application of Vee Diagrams helps students in designing experiments, therefor it can minimize the mistakes commonly done in designing experiments especiallyin practical learning. The research method was used is action research consisting of two cycles. The decrease of error in designing experiments is analyzed as a percentage at each research cycle. The data were sourced from third semester biology education students who taking biochemistry courses. Data obtained from the error analysis rubric in designing experiments, questionnaire responses of students in design experiments and vee diagrams rubric. The results showed that the application of vee diagrams can minimize errors in design experiments with the greatest decrease in errors at the stage of making hypotheses while the smallest decrease at the stage of analyzing data.
\end{abstract}

Keywords: Design Experiment, Vee Diagram, Laboratorium Learning

\section{ABSTRAK}

Merancang eksperimen merupakan pembelajaran laboratorium berbasis aktivitas dimana kegiatan laboratorium mengarah pada ide-ide ilmiah yang menekankan pada proses kualitatif dengan ujuan untuk mendorong perubahan konseptual pada mahasiswa. Rancangan eksperimen yang dibuat oleh mahasiswa masih banyak ditemukan kesalahan-kesalahan. Kesalahan dalam merancang eksperimen diharapkan dapat diminimalisir dengan penerapan vee diagram. Penerapan Vee Diagram membantu mahasiswa dalam merancang eksperimen sehingga dapat meminimalisir kesalahan-kesalahan yang biasa dilakukan dalam merancang eksperimen pada pembelajaran praktikum. Metode penelitian yang digunakan adalah penelitian tindakan yang terdiri dari dua siklus. Penurunan kesalahan dalam merancang eksperimen dianalisis dalam bentuk persentase pada tiap siklus penelitian. Data bersumber dari mahasiswa semester tiga pendidikan biologi yang menempuh mata kuliah biokimia. Data diperoleh dari rubrik analisis 
kesalahan dalam merancang eksperimen, angket respon mahasiswa dalam merancang eksperimen dan rubrik vee diagram. Hasil penelitian menunjukkan penerapan vee diagram dapat meminimalisir kesalahan dalam merancang eksperimen dengan penurunan kesalahan terbesar pada tahap membuat hipotesis sedangkan penurunan terkecil pada tahap menganalisis data.

Kata Kunci: Merancang Eksperimen, Vee Diagram, Pembelajaran Laboratorium

\section{PENDAHULUAN}

Pembelajaran sains memiliki tujuan untuk membantu peserta didik dalam memahami hal-hal yang berkaitan dengan proses-proses alam yang ada disekitarnya. Pemahaman tentang alam akan mudah diperoleh jika peserta didik sering berinteraksi dan melakukan pengamatan dengan objek-objek nyata dari alam. Kegiatan-kegiatan yang meminta peserta didik untuk berinteraksi langsung dengan objek-objek nyata ini umumnya disebut dengan kegiatan laboratorium atau yang dikenal dengan praktikum. Praktikum merupakan bagian yang tidak dapat dipisahkan dalam pembelajaran sains. Pelaksanaan praktikum membantu peserta didik membuat hubungan antara objek yang diamati dengan pengetahuan yang telah diperoleh sebelumnya, praktikum juga membantu peserta didik dalam merealisasikan teori yang telah diperoleh. Menurut Woolnough dan Allsop (dalam Psillos dan Niedderer, 2003) tujuan praktikum dikategorikan menjadi empat macam, yaitu: sebagai ilustrasi (dengan tujuan mengilustrasikan sebuah teori), sebagai latihan (mempraktekan prosedur yang standar), pengalaman (memberikan peserta didik rasa bagaimana menemukan fenomena), dan investigasi (menggiring peserta didik untuk melakukan "saintifik inkuiri"). Selain itu, pembelajaran berbasis praktik dapat digunakan sebagai alternatif pembelajaran yang dapat mendorong siswa untuk belajar aktif untuk merekonstruksi pemahaman konseptual (Mafaza, 2018).

Praktikum yang umum dilakukan adalah jenis praktikum verifikasi dalam bentuk buku resep. Pelaksanaan jenis praktikum ini cenderung memfokuskan peserta didik pada prosedur kerja yang sudah ditentukan dan mengabaikan tujuan utama dari praktikum. Praktikum biasanya dilakukan dengan cepat menyesuaikan dengan jam pelajaran yang terbatas, sehingga dalam praktikum seringkali gagal mempelajari hal-hal yang seharusnya dapat dipelajari dalam praktikum. Peserta didik sering gagal dalam menghasilkan fenomena-fenomena baru karena hanya berfokus pada resep. Praktikum dengan cara konvensional ini mendorong mahasiswa untuk membaca manual laboratorium, tetapi biasanya akan membebani mahasiswa dengan informasi yang akan diperoleh pada waktu 
yang sama (Reid dan Shah, 2005). Hal ini menyebabkan praktikum seringkali tidak mencapai tujuan yang diharapkan dan pemahaman peserta didik berkaitan dengan proses dalam praktikum tidak optimal, padahal praktikum seharusnya membantu peserta didik untuk mengembangkan pengetahuannya dengan dasar teori yang sudah diperoleh selama perkuliahan. Sejalan dengan pendapat Heuvelen (2001) dan McDermott et al. (2000), bahwa kegiatan laboratorium yang bersifat verifikasi tidak membantu dalam mengembangkan kemampuan berpikir peserta didik. Solusi untuk mengubah kebiasaan praktikum verifikasi ini, salah satunya dengan menerapkan praktikum dalam bentuk merancang eksperimen.

Merancang eksperimen merupakan kerja laboratorium yang menekankan pada proses kualitatif yang bertujuan untuk mendorong perubahan konseptual pada peserta didik. Kegiatan berfokus pada proses berpikir peserta didik melalui merumuskan masalah, membuat hipotesis, merancang prosedur kerja, mencatat hasil pengamatan, mentransformasi data dan menarik kesimpulan. Hal ini mengurangi interaksi peserta didik dengan alat-alat laboratorium dan prosedur kerja karena lebih berfokus dalam diskusi dan refleksi. Merancang eksperimen yang dilakukan oleh peserta didik ini bukan berarti mudah dilakukan. Pelaksanaan merancang eksperimen ini banyak ditemukan kesalahan-kesalahan yang dilakukan oleh peserta didik sehingga menyebabkan tujuan praktikum tidak tercapai. Hal ini umum terjadi karena kerja laboratorium dalam bentuk penyelidikan ilmiah ini merupakan hal baru bagi peserta didik dan belum terbiasa. Jenis praktikum yang umum dilakukan oleh peserta didik adalah praktikum verifikasi yang sudah mencantumkan prosedur kerja. Kesalahan dalam merancang eksperimen yang umum terjadi pada peserta didik biasanya dalam merumuskan masalah, membuat hipotesis, membuat prosedur kerja, pencatatan hasil pengamatan dan menganalisis data eksperimen yang mengakibatkan kesimpulan yang diperoleh tidak mampu menjawab masalah yang dirumuskan.

Salah satu kegiatan dalam merancang eksperimen adalah merumuskan masalah. Kesalahan yang umum terjadi pada kegiatan merumuskan masalah adalah bentuk rumusan masalah yang dibuat peserta didik kadang sulit diterapkan atau dijabarkan dalam bentuk prosedur kerja. Kesalahan dalam membuat hipotesis biasanya peserta didik menuangkan hipotesis dalam bentuk deskripsi yang panjang dan tidak memuat variabel yang jelas. Prosedur kerja yang dirancang peserta didik masih terdapat hal-hal yang membingungkan bila diterapkan dalam praktikum. Sedangkan pada bagian pencatatan hasil pengamatan dan analisis data peserta didik cenderung kesulitan dalam mengkaitkan antara teori dengan hasil pengamatan. Kesalahan-kesalahan dalam merancang eksperimen ini dapat 
diminimalisir dengan menerapkan pembelajaran praktikum yang mengakomodir tahapantahapan dalam merancang eksperimen. Salah satu pembelajaran praktikum yang dapat mengakomodir tahapan dalam merancang eksperimen adalah penerapan Vee Diagram.

Penerapan Vee Diagram digunakan untuk menganalisis deskripsi dalam panduan studi laboratorium yang dapat mengungkapkan kesenjangan konseptual tidak hanya dalam catatan laboratorium dan deskripsi pengamatan, tetapi juga latar belakang dari masalah yang muncul di lapangan (Novak dan Gowin, 2006). Vee Diagram yang terdiri dari sisi konseptual dan sisi metodologi memandu peserta didik melalui tahapan-tahapan menentukan fokus pertanyaan, menentukan dasar nilai dan teori, menentukan konsep dasar dan hipotesis, merancang pelaksanaan dalam bentuk pengamatan objek atau kejadian, pencatatan hasil, mentransformasi data hingga membuat kesimpulan dalam bentuk klaim pengetahuan dan klaim nilai. Tahapan-tahapan dalam Vee Diagram ini jika dicermati merupakan tahapan yang dikembangkan dalam merancang eksperimen. Oleh karena itu, secara tidak langsung penerapan Vee Diagram membantu peserta didik dalam merancang eksperimen sehingga dapat meminimalisir kesalahan-kesalahan dalam merancang eksperimen. Berdasarkan uraian di atas, penelitian bertujuan untuk mengetahui apakah Vee Diagram dapat meminimalisir kesalahan dalam merancang eksperimen.

\section{METODOLOGI PENELITIAN}

Metode penelitian yang digunakan adalah penelitian tindakan yang terdiri dari dua siklus. Data bersumber dari mahasiswa semester tiga pendidikan biologi yang menempuh mata kuliah biokimia. Data diperoleh dari rubrik analisis kesalahan dalam merancang eksperimen, angket respon mahasiswa dalam merancang eksperimen dan rubrik vee diagram. Penurunan kesalahan dalam merancang eksperimen dianalisis dalam bentuk persentase pada tiap siklus penelitian.

\section{HASIL DAN PEMBAHASAN}

Berdasarkan hasil penelitian diperoleh tiga data penelitian dalam bentuk persentase dan nilai yaitu: data penurunan kesalahan dalam merancang eksperimen, data respon mahasiswa dalam merancang eksperimen dan nilai hasil merancang eksperimen yang dituangkan melalui vee diagram. 
1. Analisis Kesalahan dalam Merancang Eksperimen

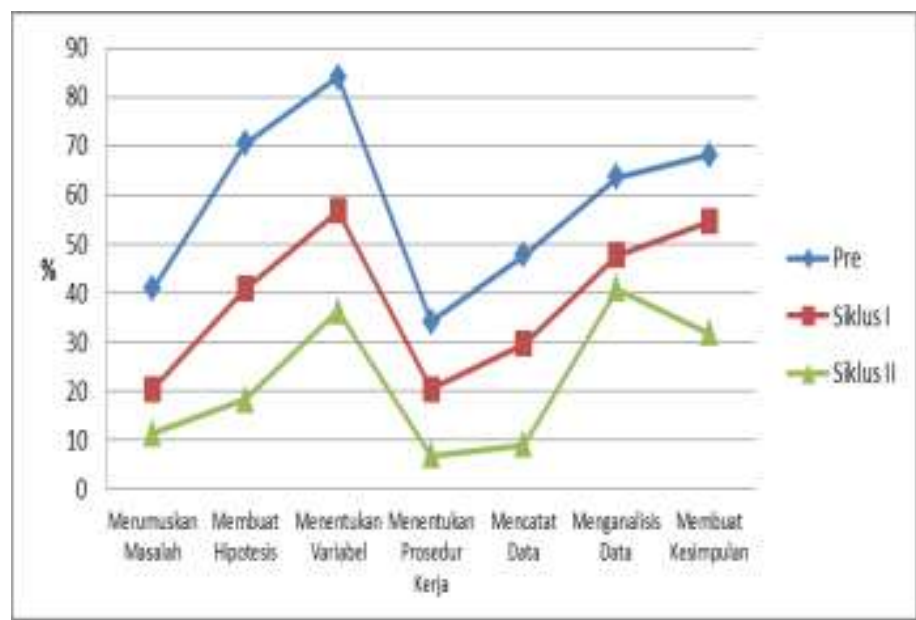

\section{Gambar 1. Grafik Analisis Kesalahan dalam Merancang Eksperimen}

Hasil analisis kesalahan mahasiswa dalam merancang eksperimen sebelum penerapan Vee Diagram ditemukan tingkat kesalahan yang paling tinggi ketika mahasiswa menentukan variabel sebesar 84, $1 \%$ dan kesalahan dengan persentase terkecil pada menentukan prosedur kerja sebesar $34,1 \%$. Setelah diperkenalkan vee diagram, pada siklus I terjadi penurunan kesalahan dalam merancang eksperimen dimana kesalahan dalam tahapan merancang eksperimen yang paling tinggi tetap pada tahapan menentukan variabel sebesar 56,8\% dan kesalahan terkecil pada tahapan menentukan prosedur dan merumuskan masalah sebesar 20,4\%. Pada siklus II kesalahan yang paling tinggi pada tahapan menganalisis data sebesar 40,9\% dan terkecil pada tahapan menentukan prosedur kerja sebesar $6,8 \%$.

2. Respon Mahasiswa dalam Merancang Eksperimen

Respon mahasiswa dalam merancang eksperimen berkaitan dengan respon mahasiswa dalam melakukan tahapan-tahapan pada merancang eksperimen yang terdiri dari 10 item pernyataan. Pada pelaksanaan sebelum diterapkan vee diagram, respon tertinggi menyatakan bahwa $72,7 \%$ mahasiswa mudah dalam menentukan alat dan bahan yang sesuai untuk menguji hipotesis. Sedangkan respon terendah menyatakan bahwa 26,3\% mahasiswa mampu menentukan kesimpulan berupa klaim nilai atau value dar pelaksanaan praktikum. Setelah diterapkan vee digram terdapat perubahan respon mahasiswa dalam melaksanakan tahapan-tahapan dalam merancang eksperimen. Respon tertinggi menyatakan bahwa $89,5 \%$ mahasiswa mudah dalam menentukan alat dan bahan 
yang sesuai untuk menguji hipotesis. Sedangkan respon terendah menyatakan bahwa 47,4\% mahasiswa mampu menentukan variabel dalam eksperimen. Adapun kejelasannya disajikan dalam Tabel 1.

Tabel 1. Respon Mahasiswa dalam Merancang Eksperimen

\begin{tabular}{llcc}
\hline No & \multicolumn{1}{c}{ Keterampilan Merancang Eksperimen } & $\begin{array}{c}\text { Sebelum } \\
(\mathbf{\%})\end{array}$ & $\begin{array}{c}\text { Setelah } \\
(\mathbf{\%})\end{array}$ \\
\hline $\mathbf{1}$ & $\begin{array}{l}\text { Mudah dalam mengidentifikasi pola hubungan/penjelasan } \\
\text { dalam menentukan masalah. }\end{array}$ & 36,3 & 47,4 \\
\hline $\mathbf{2}$ & $\begin{array}{l}\text { Mudah mengidentifikasi pola hubungan/penjelasan dalam } \\
\text { menentukan hipotesis. }\end{array}$ & 57,9 & 63,6 \\
\hline $\mathbf{3}$ & $\begin{array}{l}\text { Mudah dalam menentukan hipotesis yang sesuai dengan } \\
\text { permasalahan. }\end{array}$ & 54,5 & 78,9 \\
\hline $\mathbf{4}$ & $\begin{array}{l}\text { Mudah dalam mengidentifikasi variabel bebas dan variabel } \\
\text { terikat. }\end{array}$ & 31,8 & 47,4 \\
\hline $\mathbf{5}$ & $\begin{array}{l}\text { Mudah dalam menentukan alat dan bahan yang sesuai untuk } \\
\text { menguji hipotesis. }\end{array}$ & 72,7 & 89,5 \\
\hline $\mathbf{6}$ & $\begin{array}{l}\text { Mudah dalam merancang prosedur kerja yang sesuai untuk } \\
\text { menguji hipotesis. }\end{array}$ & 40,9 & 73,7 \\
\hline $\mathbf{7}$ & $\begin{array}{l}\text { Mampu membuat tabel hasil pengamatan yang jelas dan } \\
\text { memberikan informasi yang sesuai untuk menjawab } \\
\text { hipotesis. }\end{array}$ & 52,6 & 77,3 \\
\hline $\mathbf{8}$ & $\begin{array}{l}\text { Mampu membuat pola hubungan antara data hasil } \\
\text { pengamatan dengan teori }\end{array}$ & 36,8 & 54,5 \\
\hline $\mathbf{9}$ & $\begin{array}{l}\text { Mampu membuat kesimpulan apakah hipotesis ditolak atau } \\
\text { diterima }\end{array}$ & 57,9 & 86,4 \\
\hline $\mathbf{1 0}$ & Mampu menentukan value/nilai dari pelaksanaan praktikum & 26,3 & 59,1 \\
\hline
\end{tabular}

3. Penilaian Rancangan Eksperimen Melalui Vee Diagram

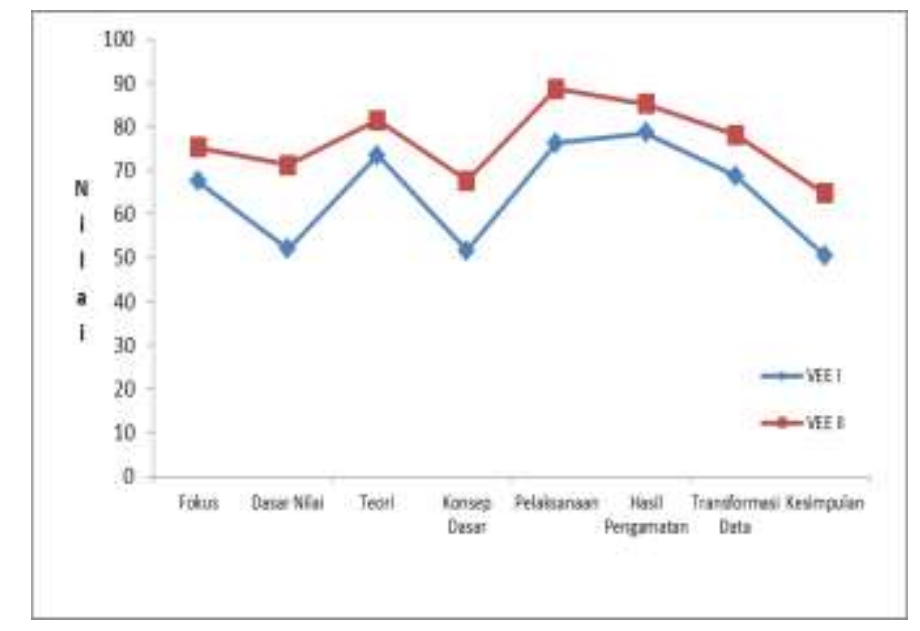

Gambar 2. Grafik Penilaian Merancang Eksperimen

Pada penilaian vee diagram siklus I komponen yang memiliki nilai tertinggi terdapat pada komponen hasil pengamatan dan nilai terendah pada komponen kesimpulan. 
Pada siklus II komponen yang memili nilai tertinggi terdapat pada komponen pelaksanaan sebesar 88,6 dan terendah pada membuat kesimpulan sebesar 64,8.

Merancang eksperimen merupakan salah satu bentuk pembelajaran laboratorium yang bermakna dimana mahasiswa dibebaskan dalam menentukan masalah, hipotesis, variabel penelitian, alat dan bahan serta prosedur kerja dalam rangka memperoleh data yang akan dianalisis untuk mencapai kesimpulan yang dapat menjawab permasalahan. Sejalan dengan pendapat Hofstein dan Mamlok (2007) bahwa pembelajaran bermakna di laboratorium akan memungkinkan jika mahasiswa diberi kesempatan untuk memanipulasi alat dan bahan agar dapat membangun pengetahuan tentang fenomena dan konsep ilmiah terkait. Rancangan eksperimen yang dibuat oleh mahasiswa terdiri dari beberapa tahapan yaitu: merumuskan masalah, membuat hipotesis, menentukan variabel, menentukan prosedur kerja, mencatat data hasil pengamatan, menganalisis data dan menarik kesimpulan berdasarkan analisis data. Berdasarkan tahapan-tahapan rancangan eksperimen yang dibuat oleh mahasiswa masih ditemukan kesalahan-kesalahan yang menyebabkan hasil dari rancangan ekperimen tidak dapat menjawab permasalahan atau mencapai tujuan yang bermakna.

Analisis kesalahan dalam merancang eksperimen pertama dilakukan sebelum dan setelah mahasiswa menerapkan vee diagram. Hasil analisis pertama ditemukan kesalahan pada tiap-tiap tahapan merancang eksperimen dengan persentase kesalahan yang cukup besar ditemukan pada tahapan membuat hipotesis, menentukan variabel, menganalisis data dan membuat kesimpulan. Pada siklus I setelah penerapan vee diagram terjadi penurunan kesalahan pada tahap-tahap merancang eksperimen yang cukup besar terutama pada tahap membuat hipotesis dan menentukan variabel. Pada tahap lainnya juga mengalami penurunan walaupun tidak sebesar tahap membuat hipotesis dan menentukan variabel. Persentase kesalahan dalam merancang eksperimen terus menurun hingga siklus II, tetapi masih terdapat tahapan merancang eksperimen yang memiliki persentase kesalahan yang lebih besar dibandingkan dengan tahapan-tahapan yang lainnya yaitu pada tahapan menentukan variabel, menganalisis data dan membuat kesimpulan.

Merancang eksperimen merupakan metode pembelajaran laboratorium berbasis aktivitas dimana kegiatan tidak dilakukan untuk memverifikasi atau mengkonfirmasi teori tetapi untuk mengarahkan ide-ide ilmiah (Singh, 2014). Kegiatan laboratorium ini akan lebih bermakna karena mahasiswa membangun pengetahuannya sendiri. Lunetta menyatakan bahwa kegiatan laboratorium akan lebih efektif jika peserta didik memiliki pengalaman dalam memahami epistemologis dan ontologis yang merupakan asumsi yang 
mendasari pengetahuan ilmiah (2007). Sebagai upaya memenuhi tujuan epistemologis maka rancangan eksperimen yang dibuat oleh mahasiswa diterapkan dalam bentuk vee diagram. Vee diagram merupakan sebuah diagram yang membuat hubungan antara konsep dan pemahaman prosedural dalam membentuk struktur pengetahuan dan proses dimana pengetahuan itu dihasilkan. Tahapan-tahapan dalam merancang eksperimen difasilitasi oleh komponen-komponen yang terdapat dalam vee diagram. Oleh karena itu, persentase kesalahan dalam merancang eksperimen semakin kecil sejalan dengan semakin seringnya mahasiswa menerapkan vee diagram dalam merancang eksperimen. Hal ini diperkuat dengan penelitian Afamasaga-fuata'i (2014) yang menyatakan bahwa struktur vee diagram yang memiliki label beragam dan pertanyaan panduan, memberikan panduan yang sistematis bagi siswa untuk membuat alasan atau jawaban dari konteks masalah dalam hal menggunakan langkah metodologi ilmiah seperti membuat hipotesis dan variabel dan melakukan percobaan. Komponen-komponen pada vee diagram juga memudahkan mahasiswa dalam memahami tahapan dalam merancang eksperimen yang merupakan bagian dari keterampilan proses sains. Vee diagram membantu dalam meminimalisir atau menghilangkan miskonsepsi dalam penyelidikan sains dan membantu mengembangkan keterampilan proses sains seperti membuat definisi operasional, menganalisis, menafsirkan, merumuskan hipotesis, merancang eksperimen, menganalisis data dan mengintegrasikan hasil dalam situasi kehidupan sehari-hari (Caliskan, 2014).

Komponen-komponen dalam vee diagram yang memfasilitasi merancang eksperimen dimulai dari fokus pertanyaan, dasar nilai, dasar teori, konsep dasar, pelaksanaan, hasil pengamatan transformasi data dan menarik kesimpulan. Kemampuan merumuskan masalah dalam merancang eksperimen difasilitasi dengan fokus pertanyaan yang merupakan fokus awal dari vee diagram. Fokus pertanyaan bertujuan untuk mempertajam sudut pandang dan meningkatkan kejelasan. Baik aspek positif dan negatif yang tertuang dalam fokus pertanyaan, keduanya penting untuk proses penyelidikan. Dengan mempertajam sudut pandang, mahasiswa akan membatasi pandangan-pandangan yang menyebabkan pertanyaan tidak berfokus atau tepat. Ketepatan penting dalam melakukan penyelidikan, dan pertanyaan yang mendefiniskan teori dengan baik akan meningkatkan keakuratan (Gowin dan Alvarez, 2005). Hasil analisis kesalahan menunjukkan penurunan kesalahan yang signifikan setelah mahasiswa menerapkan vee diagram, hal ini terlihat pada persentase respon mahasiswa dalam merumuskan masalah dan nilai fokus pertanyaan yang cukup baik. 
Dasar nilai, dasar teori dan konsep dasar yang terdapat dalam vee diagram mengarahkan mahasiswa dalam menentukan hipotesis dan variabel yang menuntun pada pelaksanaan eksperimen hingga akhirnya mampu menjawab fokus pertanyaan. Pada tahap ini mahasiswa menuliskan teori yang mampu memandu mahasiswa dan memberikan jawaban dari fokus pertanyaan sekaligus dapat menjelaskan data dan fakta yang akan ditemukan saat eksperimen. Prinsip dan konsep yang dituangkan pada tahap ini merupakan panduan bagi apa yang akan mahasiswa amati dalam eksperimen dan menjadi dasar dari hipotesis dari fokus pertanyaan hingga akhirnya memunculkan variabel penelitian. Gowin dan Alvarez (2005) menyatakan teori yang baik merupakan alat bantu, dapat merangsang ide, merangsang pertanyaan dan merupakan panduan untuk metodologi. Teori merupakan sisi pemikiran penelitian dimana ide-ide penelitian muncul berdasarkan teori. Fakta dan data yang diperoleh dari penelitian juga dijelaskan menggunakan teori. Berdasarkan analisis kesalahan, respon mahasiswa dan penilaian vee diagram mahasiswa masih terdapat kesalahan pada tahap menentukan variabel dibandingkan dalam menentukan hipotesis. Kesalahan ini disebabkan masih rendahnya pemahaman mahasiswa tentang pengertian variabel itu sendiri dan mahasiswa masih kesulitan dalam membedakan antara teori, prinsip dan konsep sehingga mempengaruhi dalam menentukan variabel yang sesuai untuk menjawab fokus pertanyaan. Sejalan dengan penelitian Hindriana (2016) kesulitan dalam membedakan antara teori, prinsip dan konsep akan mempengaruhi keputusan dalam menentukan variabel praktikum.

Tahap merancang prosedur kerja memiliki persentase kesalahan yang paling kecil, berdasarkan respon mahasiswa dalam merancang eksperimen menentukan alat dan bahan serta prosedur kerja merupakan tahapan merancang eksperimen yang paling mudah sehingga memiliki nilai vee diagram yang paling besar pada komponen pelaksanaan. Komponen pelaksanaan dalam vee diagram ini mengakomodir kemampuan dalam menentukan prosedur kerja dalam merancang eksperimen. Komponen pelaksanaan dalam vee diagram merupakan suatu peristiwa yang sedang diamati, peristiwa ini berhubungan langsung dengan fokus pertanyaan yang hasilnya dipantau dalam komponen hasil pengamatan pada vee diagram (Gowin dan Alvarez, 2005). Oleh karena itu, mencatat hasil pengamatan memiliki tingkat kesalahan yang kecil dan nilai vee diagram yang besar. Walaupun memiliki tingkat kesalahan yang kecil, beberapa kesalahan yang masih terjadi pada mencatat hasil pengamatan dapat mempengaruhi analisis data sehingga diperoleh kesimpulan yang tidak sesuai dalam menjawab fokus pertanyaan. Kesalahan dalam pencatatan hasil akan melemahkan sisi kanan vee diagram terutama pada tingkatan sisi 
kanan vee yang lebih tinggi, karena hasil ini akan mempengaruhi dalam pengambilan keputusan berkaitan dengan fokus pertanyaan yang dibuat. Solusi untuk menghindari kesalahan dalam pencatatan hasil adalah dengan menemukan cara untuk memahami peristiwa pada komponen pelaksanaan dengan menggunakan konsep-konsep dari teori yang terbaik untuk menjelaskan peristiwa tersebut (Gowin dan Alvarez, 2005).

Tahapan analisis data dalam merancang eksperimen difasilitasi dengan komponen transformasi data pada vee diagram. Persentase kesalahan yang besar masih ditemui dalam menganalisis data. Mahasiswa mengakui bahwa masih mengalami kesulitan dalam mengkaitkan teori dan konsep-konsep penting untuk menganalisis data, terlihat pada penilaian vee pada komponen konsep dasar memiliki nilai yang kurang. Kelemahan ini diakibatkan mahasiswa belum terbiasa dalam menghubungkan atau mengkaitkan antara komponen satu dengan komponen yang lain. Kebiasaan mahasiswa hanya menerima materi pelajaran dari saat sekolah menyulitkan mahasiswa ketika saat perkuliahan mereka diminta untuk mengkaitkan antara pengetahuan yang sudah mereka miliki dengan pengetahuan baru yang diperoleh dari hasil pengamatan. Sejalan dengan pendapat Gencer (2014) mahasiswa yang tidak terbiasa dengan merumuskan hipotesis, teori, hukum, melakukan observasi, melakukan eksperimen, menarik kesimpulan dan membuat hubungan diantara masing-masing elemen tersebut sebagai cara untuk membangun pengetahuan ilmiah akan menganggap bahwa merumuskan hipotesis hanya sebagai tebakan dan tidak didasarkan dari teori yang sudah diperoleh.

Tahap akhir dari merancang eksperimen adalah menarik kesimpulan yang terdiri dari klaim pengetahuan dan klaim nilai. Kesalahan dalam menarik kesimpulan masih ditemui terutama dalam perolehan klaim nilai. Respon mahasiswa menyatakan bahwa terdapat sebagian mahasiswa yang masih kesulitan dalam menentukan klaim nilai. Praktikum yang biasa dilakukan oleh mahasiswa hanya bertujuan mencapai klaim pengetahuan dan mengabaikan klaim nilai. Mahasiswa cenderung mengabaikan apa manfaat dari eksperimen yang dilakukan yang dapat diterapkan dalam kehidupan seharihari. Kebiasaan ini menyebabkan mahasiswa sulit mengkaitkan antara klaim pengetahuan yang diperoleh dalam praktikum dengan manfaat yang dapat diterapkan dalam kehidupan sehari-hari. Kesulitan ini juga ditemukan oleh (Hindriana, 2016) bahwa mahasiswa sulit menghubungkan hasil praktikum dengan pengembangan sikap yang bermanfaat dalamkehidupan sehari-hari.

Hasil persentase respon mahasiswa dalam merancang eksperimen sebelum penerapan vee diagram dan setelah menerapkan vee diagram mengalami kenaikan dengan 
persentase yang cukup besar dimana mahasiswa mudah dalam membuat hipotesis, merancang prosedur kerja, menganalisis data dan membuat kesimpulan. Peningkatan ini menunjukkan penerapan vee diagram memudahkan mahasiswa dalam merancang dan melakukan eksperimen. Vee diagram yang dibuat oleh mahasiswa sebagai rancangan eksperimen sekaligus sebagai laporan percobaan yang lebih sederhana tetapi berfokus pada pengetahuan yang akan diperoleh. Vee diagram lebih disukai untuk menyiapkan laporan percobaan, membuat jembatan antara teori dan praktek dan menyediakan pandangan analitis, lingkungan belajar visual dan bermakna (Keles dan Ozsoy, 2009).

Secara keseluruhan penerapan vee diagram dapat meminimalisir kesalahan dalam merancang eksperimen dimana komponen pada vee diagram dapat memandu mahasiswa dalam tahapan merancang eksperimen yang biasa dilakukan oleh ilmuwan. Vee diagram sebagai manual laboratorium yang mendorong mahasiswa untuk berpikir sebagai ilmuwan sebelum memasuki laboratorium sekaligus memahami cara mendesain eksperimen yang lebih baik ( Safdar dkk, 2013; Keles dan Ozsoy, 2009).

\section{SIMPULAN}

Vee diagram mampu meminimalisir kesalahan dalam merancang eksperimen dimana mahasiswa dipandu oleh tahapan pada sisi konseptual dan sisi metodologi pada vee diagram sehingga mahasiswa lebih mudah memahami tahapan dalam merancang eksperimen berdasarkan teori yang sudah mereka peroleh sehingga dapat mengevaluasi kesalahan mereka sendiri dalam merancang eksperimen.

\section{DAFTAR PUSTAKA}

Afamasaga-Futa'i, K dan Sooaemalelagi, L. (2014). Student Teachers' Mathematic Attitudes, Authentic Investigation and Use of Metacognitive Tools. J. Math Teacher Educ. 1-38.

Alvares dan Risko. (2007). The Use of Vee Diagram With Third Graders as A Metacognitive Tool for Learning Science Concept. Departement of Teaching and Learning Teaching and Learning Presentations.

Caliskan, I. (2014). The Perceptions of Pre-Service Science Teacher's About Using Vee Diagrams and Electronic Portfolios in Physics Laboratuary Course. Academic Journal, Educational Research and Reviews, 9(6), 173-182.

Dhanapal, S dan Shan, E W. (2014). A Study on The Effectiveness of Hands-on Experiments in Learning Science Among Year 4 Student. International Online Journal of Primary Education. Volume 3 Issue 1. 
Gencer, A. S. (2014). Analyzing Vee Diagram Reflection To Explore Pre-Service Science Teachers' Understanding The Nature of Science in Biology. Eurasia Journal of Mathematic, Science \& Technology, 10 (5), 437-446.

Gowin dan Alvarez. (2005). The Art of Education With V Diagram. New York: Cambridge University Press.

Heuvelen, A.A. (2001). "Millikan Lecture 1999: The Workplace, Student Minds, and Physics Learning Systems.” Am. J. Phys. 69(11), 1139-1146.

Hindriana, A.F. (2016). The Development of Biology Practicum Learning Based on Vee Diagram For Reducing Student Cognitive Load. Journal of Education, Teaching and Learning, 1 (2), 61-65.

Hofstein, A dan Mamlok, R. (2007). The Laboratory In Science Education: The State of Art. Chemistry Education Research and Practice. 8(2), 105-107.

Keles, Ozsoy. (2009). Preservice Teacher's Attitudes Toward Use of Vee Diagrams in General Physics Laboratory. International Electronic Journal of Elementary Education. Vol 1 Issue 3 Juni 2009.

Lunetta, V.N. Hofstein, A. Dan Clough, M.P. 2007. Learning and Teaching in The School Science Laboratory: An Analysis of Research, Theory and Practice. In.N., Leaderman. and S. Abel (eds,). Handbook of research on science education. (393441).

Mafaza, M., Mulyani, S., \& Ridlo, S. (2018). Penerapan Perangkat Pembelajaran Berbasis Praktikum Invertebrata Untuk Meningkatkan Kemampuan Berpikir Kritis Dan Sikap Ilmiah Siswa SMA. Jurnal Mangifera Edu, 2(2), 103-114.

McDermott, L.C., P.S. Shafer and C.P. Constantinou. (2000). "Preparing teachers to teach physics and physical science by inquiry." Phys. Educ, 35(6), 411-416.

Novak, J. D \& Gowin D. (2006). Learning How To Learn. Cambridge, MA: Cambridge University Press.

Psillos dan Niedderer. (2003). Teaching and Learning In The Science Laboratory. New York : Kluwer Academic Publisher.

Reid, N dan Shah, I. (2007). The Role of Laboratory Work in University Chemistry. Chemistry Education Research and Practice, 8(2), 172-185.

Safdar, Hussain, Shah dan Tasnim. (2013). Make The Laboratory Work Meaningful Through Concept Maps and Vee. IOSR Journal of Research of Method In Education, 3(2), 55 -60.

Singh, G. (2014). Review of Research on School Science Laboratory Work With Special Emphasis on Physics Education. Mumbai: Homi Bhabha Centre For Science Education. 
Jurnal Mangifera Edu, Volume 4, Nomor 2, Januari 2020, Halaman 94-106

Staver, qJ.R. (2007). Teaching Science. France: Nouvelle Gonnet. 